\title{
ASSESSMENT OF AWARENESS LEVEL OF HYDROPONIC TECHNOLOGIES AMONG CROP FARMERS IN IBADAN NORTH LOCAL GOVERNMENT AREA OF OYO STATE NIGERIA
}

\author{
*OYETORO John Oyewole, *ADETUNBI S.I, ${ }^{* *}$ JOLAYEMI J.O and "TIAMIYU A.O
}

\author{
*Department of Agricultural Extension and Rural Development, \\ Ladoke Akintola University of Technology, Ogbomoso, Nigeria \\ ** Department of Agricultural Science Education, \\ College of Education, Oro, Kwara state, Nigeria.
}

DOI: https://doi.org/10.51193/IJAER.2020.6607

\begin{abstract}
The study assessed awareness level of using hydroponic technologies among crop farmers in Ibadan North Local Government Area of Oyo state. The study employed the use of interview schedule in the collection of data from fifty (50) respondents. The mean age of the respondents is 40.22 years, majority $(88.0 \%)$ of the respondents in the study were male, most of the respondents $(66.0 \%)$ were married, most of the respondents are literate with mean year spent in schooling was 17.20 years, most $(66.0 \%)$ of the respondent were aware of bucket as an hydroponic technology, most $(58 \%)$ of the respondents in the study area believes utilizing hydroponic technologies require time and commitment. The major constraints in the study area to the utilization of hydroponic technologies was lack of technical know how of hydroponic technologies. Hypothesis tested revealed that socio-economic characteristics such as Gender $\left(X^{2}=28.880, P=0.000\right)$, Marital status $\left(X^{2}=74.400, p=0.000\right)$, Religion $\left(X^{2}=3.920, p=0.048\right)$, Education $\left(X^{2}=40.240, p=0.000\right)$, Primary occupation $\left(X^{2}=64.800, p=0.000\right)$, secondary occupation $\left(X^{2}=9.200, p=0.000\right)$, Household $\left(X^{2}=14.440, p=0.071\right)$, Social group membership $\left(\mathrm{X}^{2}=13.520, \mathrm{p}=0.000\right)$ were significantly associated with the awareness level of using hydroponic technologies. The study recommended that Government, private investors, companies manufacturing equipment for hydroponics farming and all stakeholders should not only encourage but assist in research and training of all interested on the technicalities involved in hydroponics technologies.
\end{abstract}

Keywords: Technology, Hydroponic Technology, Local Hydroponic Technologies, Crop Production 
International Journal of Agriculture and Envrionmental Research

ISSN: 2455-6939

Volume: 06, Issue: 06 "November-December 2020"

\section{INTRODUCTION}

Hydroponics is a practice of raising plants by using water (Arshad, 2019). Vertical Roots (2020) viewed Hydroponics as a way to skip the soil, sub in a different material to support the roots of the plant, and grow crops directly in nutrient-rich water. Woodford (2020) observed that despite benefits of hydroponics have sometimes been questioned, there seem to be many advantages in growing without soil. Some hydroponic growers have found they get yields many times greater when they switch from conventional methods. Because hydroponically grown plants dip their roots directly into nutrient-rich solutions, they get what they need much more easily than plants growing in soil, so they need much smaller root systems and can divert more energy into leaf and stem growth. With smaller roots, you can grow more plants in the same area and get more yield from the same amount of ground (which is particularly good news if you're growing in a limited area like a greenhouse or on a balcony or window-ledge inside). Hydroponic plants also grow faster. Many pests are carried in soil, so doing without it generally gives you a more hygienic growing system with fewer problems of disease. Since hydroponics is ideal for indoor growing, you can use it to grow plants all year round.

In hydroponic farming, Kibiti (2017) stated that plants are grown without the use of soil. Plants receive all the essential nutrients from a nutrient-rich water-based solution. There is a variety of hydroponic methods in which plants can either grow in a non-soil medium or directly in the solution. Hydroponic intervention involve more capital than conventional production systems ininfrastructure having positive impact on productivity and growth (Imran and Niazi, 2011).

The global food crisis is increasing with alarming speed and force, necessitating nations and international organizations all over the globe to respond with a strategic and long term approach. It has been observed that the current crisis is caused by a web of interconnected forces involving agriculture, energy, climate change, trade, and new market demands from emerging markets and therefore has grave implications for economic growth and development, international security, and social progress in developing countries (Centre for Strategic and International Studies (CSIS), 2008). Sustainable food production technologies could be used as an alternative for producing food all the year round. Hydroponics technology is one of such technologies. Despite the importance of the hydroponics technology on enhancing food security and environmental control, the adoption of the hydroponics technology by the small scale crop farmers in Nigeria has stagnated. On this note, the study generally assessed the awareness level of hydroponic technologies among crop farmers while specifically the study determined the awareness level of respondent on hydroponic farming technology; examined the perception of farmers towards hydroponic farming technologies and determined the constraints to the practice of hydroponic farming. 
International Journal of Agriculture and Envrionmental Research

ISSN: 2455-6939

Volume: 06, Issue: 06 "November-December 2020"

\section{METHODOLOGY}

Multistage sampling procedure was used to select 50 out of the 185 registered crop farmers in Ibadan North Local Government Area. Well-structured questionnaire was used to elicit information from the respondents based on the stated objectives of this research work. Descriptive statistics scuh as freqeuncy, percentage and mean was used to analyse the stated objectives while Chi-square was used to test the stated hypothesis.

\section{RESULT AND DISCUSSION}

\section{Socio-Economic Characteristics of Respondents}

Table 1 shows that most of the respondents $(62.0 \%)$ fell between the age of $\leq 40$ years. $32.0 \%$ of the respondents were in the range of 41-60 years while few (6.0\%) were between the range of 61 years and above. The mean age of the respondents was 40.22 years. This implies respondent were youthful and in their middle ages.

Table 1 also revealed that the gender distribution of respondents in the study area and the table revealed that majority (88.0\%) of respondents in the study area were male and few (12.0\%) of the respondents were female. This deduces that male were perceived to be more energetic than females especially in provision of labour power in agricultural activities. This is in agreement with previous study made by Kimaro et al, (2015) which shows that majority of youths who participate in Agriculture were males. Also the result in Table 3 shows that few (24.0\%) of the respondents were single, $2.0 \%$ were separated, $2.0 \%$ were divorced, $6.0 \%$ were widow/widower and most (66.0\%) were married. This implies that respondents in the study area may be responsible to have a family.Table 3 also portrayed that few (36.0\%) of the respondentswere practicing Islam while most $(64.0 \%)$ were Christians. This implies that all the respondents belong to one religion or the other.

The educational status was included in the table 1 and it indicates that $2.0 \%$ had no formal education, few (16\%) of the respondents has 7-12 years of formal education while majority (82\%) had 13 years and above level of formal education. The mean years of the formal education was 17.20 years. This implies that most of the respondents in the study area are literate. Table 3 also indicates that most $(62.0 \%)$ of the respondents primary occupation is farming, $26.0 \%$ were civil servants, $2.0 \%$ were artisan, $8.0 \%$ were involved in Trading, and 2.0\% in Transport service. This shows that the respondent main occupation is farming.

Table 1 also explained that half (50\%) of the respondents secondary occupation was Farming, $10.0 \%$ were artisan, $30.0 \%$ were traders, $2.0 \%$ involved in transport services and $8.0 \%$ of the respondents secondary occupation was indicated as others like fashion designing, public 
speakers, football Research (Compiler) and so on. This implies that few of the respondents who are businesspersons, employees in both public and private sectors had farming as their secondary occupation. Table 1 further explained the household size of the respondents and it indicate that $46.0 \%$ of the respondents had household of $\leq 5$ persons, almost half $(54.0 \%)$ of the respondents had household size of 6-10 persons. The mean household size was 6 persons and thus indicates that farmers in the study area had a moderate household size.

The annual income of respondents as stated in table 1 shows that most (56\%) of the respondents annual income fell between $\leq \# 300,000,20 \%$ fell between \#301,000 - \#600,000 while few (2\%) fell between \#601,000 and above. The mean annual income from crop production was $\# 1,017,660.00$. This insinuates crop farmers live above poverty level. Table 1 also indicated social organization membership. Majority $(76.0 \%)$ of the respondent were member of a social organization while few $(24.0 \%)$ of the respondents belong to no social organization. This implies that membership of social organization may provide exposure to gather innovations in crop production such as the use of hydroponic technologies.

Table 1: Distribution of respondents according to socio-economic characteristics

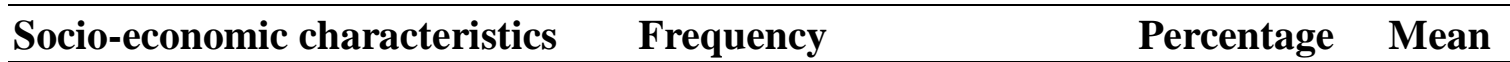

Age (years)

$\leq 40$

$41-60$

61 and above

6.0

\section{Gender}

Male

Female

\section{Marital status}

Single

Separated

Divorced

Widow 
International Journal of Agriculture and Envrionmental Research

ISSN: 2455-6939

Volume: 06, Issue: 06 "November-December 2020"

\section{Religion}

Islam

18

36.0

Christianity

32

64.0

\section{Education}

No formal education

1

$\leq 6$ years

7-12 years

8

16.0

13 years and above

41

82.0

Primary occupation

Farming

31

62.0

Civil servant

13

26.0

Artisan

1

2.0

Trading

4

8.0

Transport service

1

2.0

Secondary occupation

Farming

Civil servant

Artisan

5

10.0

Trading

15

30.0

Transport services

1

2.0

Others

4

8.0

\section{Household size}

$\leq 5$

23

46.0

6-10

27

54.0

6

11 and above 
International Journal of Agriculture and Envrionmental Research

ISSN: 2455-6939

Volume: 06, Issue: 06 "November-December 2020"

\section{Annual income}

$\leq 300,000$

$301,000-600,000$

601,000 and above

Society or group

Yes

No

12
56.0

20

1017660.00

24

24.0

Source: Field survey 2019

\section{Level of awareness of hydroponic technologies}

Table 2 indicates that most of the respondent $(66.0 \%)$ were aware of bucket hydroponic technology. $8.0 \%$ aware of rain boot, $40.0 \%$ aware of plate, $32.0 \%$ aware of net pot, $18.0 \%$ aware of banana stem, $18.0 \%$ aware of Trough, $54.0 \%$ aware of Ropes, $58.0 \%$ aware of plastic bottles and pipes, $2.0 \%$ aware of palm fronds and $32.0 \%$ aware of Tray. This implies that the awareness level of bucket as a hydroponic technology is high in the study area followed by plastic bottles, and pipes. Palm fronds had lowest awareness claim on hydroponic technologies, which implies that the utilization of palm fronds as an hydroponic technology is still very low in the study area.

Table 2: Distribution of respondents according level of awareness of hydroponic technologies

\begin{tabular}{lll}
\hline Local Hydroponics Technologies* & Aware & Unaware \\
\hline & & \\
Bucket & $33(66.0)$ & $17(34.0)$ \\
Rain boot & $4(8.0)$ & $46(92.0)$ \\
Plate & $20(40.0)$ & $30(60.0)$ \\
Net pot & $16(32.0)$ & $34(68.0)$ \\
Banana stem & $9(18.0)$ & $41(82.0)$ \\
Trough & $9(18.0)$ & $41(82.0)$ \\
Rope & $27(54.0)$ & $23(46.0)$ \\
Plastic bottles & $29(58.0)$ & $21(42.0)$ \\
Pipes & $29(58.0)$ & $21(42.0)$ \\
Palm fronds & $1(2.0)$ & $49(98.0)$ \\
Tray & $16(32.0)$ & $34(68.0)$ \\
\hline
\end{tabular}

Source: Field survey 2019. 
International Journal of Agriculture and Envrionmental Research

ISSN: 2455-6939

Volume: 06, Issue: 06 "November-December 2020"

\section{* Multiple Response}

\section{Perception of crop farmers towards hydroponic technologies}

Table 3 reveals the distribution of respondents according to their perception toward hydroponic technology and it portrays that respondents in the study area believed hydroponic technology requires time and commitment,this was ranked first with a Weighted Mean Score (WMS) of 4.24.This implies that to give satisfactory yield, hydroponic plantneeds proper care, followed the interest of farmers towards hydroponic technology was ranked second with a weighted mean Score (WMS) of 4.16 which implies that majority of the respondent in the study area are interested in utilization of hydroponic technology, followed by market for hydroponic product which was ranked third with a weighted mean score (WMS) of 4.12 this implies that respondents believed that the demand for hydroponic product would be high due to its quality while hydroponic technology does not require more land to start with was ranked last with weighted mean score (WMS) of 2.40. This implies that the utilization of hydroponic technology is perceived to be economical and the cost-benefit ratio is high.

Other perception of the farmers in the study area towards hydroponic technologies are: Hydroponics can be used to reduce food security (WMS=3.84), Hydroponic does not require a technical skill (WMS=3.54), Hydroponics product are nutritious (WMS=3.52), Hydroponics are meant for literate farmers (WMS=3.36), Disease and pest cannot be easily controlled in hydroponics (WMS=3.34), Hdroponics is cheap to start(WMS=3.16), Hydroponic does not require high cost of investment (WMS=3.12),Hydroponics is not stressful (WMS=3.06) was ranked eleventh, thirteenth and fourteenth respectively .

Table 3: Perception of crop farmers towards hydroponic technologies

\begin{tabular}{llllll}
\hline Crop farmer's perception* & $\begin{array}{l}\text { Strongly } \\
\text { Agreed }\end{array}$ & Agreed & Undecided & $\begin{array}{r}\text { Disagreed } \begin{array}{l}\text { Strongly } \\
\text { disagreed }\end{array} \\
\text { WMS }\end{array}$ & Rank \\
\hline
\end{tabular}

Hydroponics are meant for

literate farmers

$16(32.0)$

$10(20.0) \quad 3(6.0)$

$18(36.0)$

$3(6.0)$

3.36

$7^{\text {th }}$

Disease and pest spread

quickly in hydroponics

$4(8.0)$

$6(12.0) \quad 16(32.0)$

$21(42.0)$

$3(6.0)$

$2.7413^{\text {th }}$

Hydroponics product are

Nutritious

$13(26.0)$

$7(14.0)$

$25(50.0)$

$3(6.0)$

$2(4.0)$

$3.52 \quad 6^{\text {th }}$

Hydroponics is cheap to

Start

$6(12.0)$

$10(20.0)$

$23(46.0)$

$8(16.0)$

$2(4.0)$

3.16

$9^{\text {th }}$

Hydroponics can be used 
International Journal of Agriculture and Envrionmental Research

ISSN: 2455-6939

Volume: 06, Issue: 06 "November-December 2020"

to reduce food scarcity

$21(42.0)$

$9(18.0)$

$15(30.0) 1(2.0)$

$4(8.0)$

3.84

$4^{\text {th }}$

Hydroponics farming is

too complex to understand

$8(16.0) \quad 9(18.0)$

$13(26.0)$

$17(34.0) \quad 3(6.0)$

3.04

$12^{\text {th }}$

Hydroponics require time

and commitment

$29(58.0) \quad 8(16.0) \quad 11(22.0)$

0

$2(4.0)$

4.24

$1^{\text {st }}$

Hydroponics is not stressful

$4(8.0)$

$10(20.0) 20(40.0)$

$11(22.0) \quad 5(10.0) \quad 3.06$

$11^{\text {th }}$

Hydroponics does not

require high cost of

investment

$4(8.0) \quad 8(16.0)$

$22(44.0)$

$10(20.0)$

$6(12.0)$

$3.1210^{\text {th }}$

Hydroponics does not

require more land to start

with

$15(30.0) \quad 11(22.0) \quad 16(32.0) \quad 5(10.0) \quad 3(6.0) \quad 2.40 \quad 14^{\text {th }}$

Hydroponics does not

require a technical skill

$5(10.0) \quad 4(8.0)$

$12(24.0)$

$17(34.0) \quad 12(24.0) \quad 3.54$

$5^{\text {th }}$

There is no market for

hydroponic product

$1(2.0) 0$

$11(22.0)$

$18(36.0)$

$20(40.0) 4.12$

$3^{\text {rd }}$

Disease and pest cannot be

easily controlled in

hydroponics

$5(10.0) \quad 6(12.0)$

$16(32.0) \quad 13(26.0) \quad 10(20.0) \quad 3.34$

$8^{\text {th }}$

No interest to practice

hydroponic farming

$2(4.0) \quad 3(6.0)$

$3(6.0)$

$19(38.0) 23(46.0) 4.16$

$2^{\text {nd }}$

Source: Field survey 2019.

( ) represents percentage

* multiple responses

\section{The constraints affecting the utilization of hydroponic technology}

Table 4 shows the distribution of respondents according to the constraints to the awareness level of hydroponic technologies on the study area and it indicates that Majority $76.0 \%$ of the respondents claimed government policy as serious constraints affecting the utilization of hydroponic technology, $46 \%$ of the respondents indicated that distance from farm is a minor problem to the practicing of hydroponic technology. Majority (96\%) of the respondents claimed that lack of technical know how is one of the major problem facing utilization of hydroponic technologies, $76 \%$ of the respondents indicates that inadequate power supply is a serious constraint, $86.0 \%$ of the respondents claimed that literacy level also constituted serious constraints to the utilization of hydroponics technology while $70.0 \%$ of the respondents indicates that high cost of investment as a serious constraint. This deduces that major constraints to the utilization of hydroponics technologies among crop farmers is lack of technical know-how. 
International Journal of Agriculture and Envrionmental Research

ISSN: 2455-6939

Volume: 06, Issue: 06 "November-December 2020"

Table 4: The constraints affecting the utilization of hydroponic technology.

\begin{tabular}{llll}
\hline Constraints of hydroponics technologies utilization & *Serious & Mild & \multicolumn{2}{l}{ Not a constraint } \\
\hline Government policy & $38(76.0)$ & $18(36.0)$ & $4(8.0)$ \\
Distance from farm & $23(46.0)$ & $18(36.0)$ & $9(18.0)$ \\
Technical know-how & $48(96.0)$ & $2(4.0)$ & - \\
Power supply & $38(76.0)$ & $9(18.0)$ & $3(6.0)$ \\
Literacy level & $43(86)$ & $6(12.0)$ & $1(2.0)$ \\
High cost of investment & $35(70)$ & $15(30.0)$ & - \\
\hline
\end{tabular}

Source:Field survey, 2019

( ) represents percentage

* multiple responses

\section{Hypothesis testing}

There is no significant association between socioeconomic characteristics of the respondents and the awareness level of using hydroponic technologies.

The result in the table 5 shows that selected socioeconomic characteristics such as Gender $\left(\mathrm{X}^{2}=\right.$ $28.880, \mathrm{P}=0.000$ ) this implies that the percentage of male practicing agriculture is higher than female because male were perceived to be more energetic than female especially in provision of labour power in agricultural activities which influence the rate at which they area were of hydroponic technologies. Marital status $\left(X^{2}=74.400, p=0.000\right)$, this implies that married men have more responsibilities to cater for which influences their pursuit for increase in the level of agricultural practice thereby making them to seek for innovative technologies such as hydroponic technologies for meeting their responsibilities. Religion $\left(\mathrm{X}^{2}=3.920, \mathrm{p}=0.048\right)$, some religion give room for training and educational program which open up their devotee to latest development and technologies while some religion does not. Those religions that give room for exposure to latest development and innovative technologies makes their devotees to be aware technologies like hydroponics. Education $\left(X^{2}=40.240, p=0.000\right)$, this portrays that farmer with higher level of education tend to be more expose to hydroponic technologies compare to farmers with low level of education. Primary occupation $\left(X^{2}=64.800, p=0.000\right)$, this implies that someone who practices farming as a primary occupation has interest in seeking for knowledge on innovative technologies related to farming thereby affecting the awareness level of hydroponic technologies. Secondary occupation $\left(X^{2}=9.200, p=0.000\right)$, this implies that farmers who have their major source of income outside farming tend to have low or little interest in seeking for knowledge on 
innovative technologies related to farming which result to low awareness of hydroponic technologies. Household $\left(\mathrm{X}^{2}=14.440, \mathrm{p}=0.071\right)$, thus shows that farmers with large households seeks for ways by which food security will be attained all through the year in their family thereby making them to tend to be aware of hydroponic technologies compare to farmers with smaller household size who does not have much responsibility to cater for. Group $\left(X^{2}=13.520\right.$, $\mathrm{p}=0.000$ ). This implies that farmers who belong to group that encourages innovation in agriculture are likely to be aware of hydroponic technologies.

Table 5: Chi-square analysis showing the relationship between selected socio-economic characteristics of the respondents and the level of using hydroponic technologies

\begin{tabular}{lllcl}
\hline Socio-economic characteristics & $\mathbf{X}^{\mathbf{2}}$ & Df & P-value & Remark \\
\hline Age & & & & \\
Gender & 17.000 & 24 & 0.849 & Not significant \\
Marital status & 28.880 & 1 & 0.000 & Significant \\
Religion & 74.400 & 4 & 0.000 & Significant \\
Education & 3.920 & 1 & 0.048 & Significant \\
Primary Occupation & 40.240 & 11 & 0.000 & Significant \\
Secondary occupation & 64.800 & 4 & 0.000 & Significant \\
Household & 39.200 & 4 & 0.000 & Significant \\
Annual income & 14.440 & 8 & 0.071 & Significant \\
Group & 13.920 & 16 & 0.605 & Not significant \\
\hline
\end{tabular}

Source: Field survey, 2019

\section{CONCLUSION AND RECOMMENDATIONS}

This study concluded that majority of the respondents are male, married, Christians, and literate.Most of the respondents are aware of bucket as a hydroponic technology.The majority of the respondents in the study area believes hydroponics technology require time and commitment. Constraints encountered by the respondents in the study area to the utilization of hydroponic technologies were lack of technical know-how, government policy, distance, inadequate power supply, literacy level and high cost of investment.

The following recommendations were made from the study:

- Government, private investors, companies manufacturing equipment for hydroponic farming and all stakeholders should not only encourage but assist in research and training of all interested on the technicalities involved in hydroponics technologies.

- The cost of the hydroponics system is determined by the type of materials used in the construction. Suitable locally available materials should be sourced for to construct 
hydroponics systems and this will go a long way to reduce the cost of hydroponics technology.

- Limited access to agricultural loans affects agricultural production and investment. The government should provide grants, subsidy or low interest credit facilities to smallholder hydroponic farmers who are interested in hydroponics technologies. The promotion of hydroponic technologies can help to reduce food scarcity in Nigeria.

\section{REFERENCES}

Arshad Mahmood Malik (2019). Impact of Vegetable Production through Hydroponics Technology on Agricultural Development and Trade in Pakistan: A computable general equilibrium analysis. Unpublished thesis submitted in partial fulfillment of the requirements for the degree of Doctor of Philosophy in Economics Department of Economics, Preston University Kohat Islamabad Campus.

Center of strategic and international Studies (2008). International Energy Outlook 2008. Retrieve from https://www.csis.org/events/international-energy-outlook-2008.

Imran, M., and Niazi, J. (2011). Infrastructure and growth. The Pakistan Development Review, 355-364.

Kibiti J.G (2017). Factors Influencing Adoption of Urban hydroponic Farming. A case of Meru Town, Meru County, Kenya. A Research report Submitted in Partial Fulfilment of the Requirements for the Award of the Degree of Master of Arts in Project Planning and Management of the University of Nairobi.

Kimaro P.J, Towo N.N and Moshi .H (2015). Determinants of rural youth's participation in agricultural activities: The case of kahe east ward in Moshi rural district, Tanzania. International Journal of Economics, Commerce and Management. United kingdom 3(2), . http://ijecm.co.uk/

Vertical Roots (2020). The What and Why of Hydroponic Farming. https://www.verticalroots.com/the-what-and-why-of-hydroponic-farming/

Woodford C. (2020). Hydroponics https://www.explainthatstuff.com/hydroponics.html 